González-Sánchez, K., Flores-Alvarado, B., Montiel-Barrantes, P., Gómez-Arce, G., \& Alvarado, J. J. (2021). Ascidian diversity of Costa Rica, including new records for the North Pacific. Revista de Biología Tropical, 69(Suppl. 2), S234-S245. https://doi.org/10.15517/rbt.v69iS2.48318

\title{
Ascidian diversity of Costa Rica, including new records for the North Pacific
}

\author{
Kaylen González-Sánchez ${ }^{1,2}$; (D) https://orcid.org/0000-0002-7208-9302 \\ Bryan Flores-Alvarado ${ }^{1,2}$; (iD https://orcid.org/0000-0003-2826-8810 \\ Paula Montiel-Barrantes ${ }^{1,2}$; (D) https://orcid.org/0000-0002-5945-8396 \\ Gonzalo Gómez-Arce ${ }^{1,2}$; (D) https://orcid.org/0000-0002-5200-0390 \\ Juan José Alvarado ${ }^{1,2,3}$; (D) https://orcid.org/0000-0002-2620-9115
}

1. Centro de Investigación en Ciencias del Mar y Limología (CIMAR), Universidad de Costa Rica, 11501-2060, San José, Costa Rica; kaygs95@gmail.com,bryfloalv@gmail.com,mapamoba22@gmail.com,gongomeza@gmail.com, juanalva76@yahoo.com

2. Escuela de Biología, Universidad de Costa Rica, 11501-2060, San José, Costa Rica.

3. Museo de Zoología, Centro de Investigación en Biodiversidad y Ecología Tropical (CIBET), Universidad de Costa Rica, 11501-2060, San José, Costa Rica.

Received 30-I-2021. Corrected 23-IV-2021. Accepted 19-VII-2021.

\begin{abstract}
Introduction: The class Ascidiacea has about 3000 species, which fulfill various roles in the ecosystem, for example, they filter high amounts of particles, and are shelter and food for other animals. Furthermore, the group has a high number of invasive species reported. In Costa Rica, ascidians have been barely studied.

Objective: In this study, we aim to describe the diversity of ascidians in Costa Rica from new samplings in Área de Conservación Guanacaste, North Pacific, and by compiling previous reports for the entire country in order to improve the group's state of knowledge.

Methods: Samples were collected during two field trips between 2018 and 2019, at six sites within the Gulf of Santa Elena and three sites near the Murcielago Islands area. The specimens were dissected and analyzed in detail to determine the species. All the identifications were compared with the available information from literature and from museum collections. Literature, collections databases of the National Museum of Natural History, Smithsonian Institution and the new material collected were used to create an updated taxonomic list. Results: A total of eight species were obtained from 70 specimens. Of these, five are new reports for the country, which increase to 22 species the total number reported for Costa Rica. The most common species was Rhopalaea birkelandi, whose presence was higher in Santa Elena Bay.

Conclusions: This study improved the knowledge of ascidian diversity in Costa Rica. Polyandrocarpa anguin$e a$, reported for the first time, is considered invasive in other areas, which suggests the necessity of a continuous monitoring of its population. It is necessary to include more areas of the country since almost all the reported species come from the North Pacific; the diversity of ascidians from other parts of the country, especially the Caribbean, is still unknown.
\end{abstract}

Key words: Ascidiacea; distribution; systematics; taxonomy; new reports. 
Ascidians are the most diverse class within the subphylum Tunicata, with around 3000 described species (Shenkar \& Swalla, 2011). The ascidians are characterized for having an external tunic made up mainly of cellulose (Abbott, Newberry, \& Morris, 1997). The current classification for the class divides them into three orders, which are determined by the internal structure of the branchial sac: Aplousobranchia, Stolidobranchia y Phlebobranchia (Lahille, 1886). These organisms exhibit solitary individuals or colonial forms, with zooids with different structural and functional relationships inside a colony (Moreno-Dávila, 2013). Ascidians inhabit many marine environments, from the intertidal zone to abyssal depths (Shenkar \& Swalla, 2011). They mostly feed by filtering organic matter and plankton (Petersen, 2007).

This group serves as a substrate and/or refuge for smaller organisms, it is also part of the diet of marine turtles, such as Eretmochelys imbricata. Besides, they are successful competitors for primary substrate (Carrión-Cortez, Canales-Cerro, Arauz, \& Riosmena-Rodríguez, 2013; Darwin \& Klebba, 2007; Fletcher, Forrest, \& Bell, 2013; Marin \& Anker, 2008).

Ascidians are among the taxa with the highest number of introduced species reported (Evans, Erwin, Shenkar, \& López-Legentil, 2017), which are transported principally as macrofouling attached to the ships hull's and their larvae through ballast water (Lambert, 2002). Ascidians are successfully facing rough predatory and environmental conditions (Lambert, 2002; Lambert, 2007). It is crucial to set a baseline in order to keep track of invasive species and their effects, hereby the importance of taxonomic knowledge of the group.

Despite their ecological importance and usefulness, and being reported as abundant in the rocky bottom of the North Pacific of Costa Rica; few studies have been carried about their taxonomy and ecology (Cortés, 2009; Nova-Bustos, Hernández-Zanuy, \& ViquezPortuguez, 2010; Tokioka, 1971; Tokioka, 1972). The ascidians identification involves a very detailed, time consuming and specialized process; demanding high taxonomic experience and motor skills for delicate dissections and preservation (Stefaniak, Lambert, Gittenberger, Zhang, \& Whitlatch, 2009; Turon, Casso, Pascual, \& Viard, 2020); which could have led to the limited knowledge in the region. This study aims to describe the diversity of ascidians in Costa Rica, based on new samplings in the North Pacific, previous reports in the literature, and museum databases available online, in order to improve and update the knowledge on species diversity.

\section{MATERIALS AND METHODS}

Sites: Sampling took place on two field trips: from July $1^{\text {st }}$ to August $3^{\text {rd }} 2018$, and from July $15^{\text {th }}$ to July $19^{\text {th }} 2019$. The samples were collected at nine sites distributed in the Área de Conservación Guanacaste (ACG, Guanacaste Conservation Area) in Costa Rica's North Pacific (Fig. 1). This area has a seasonal upwelling that goes along December through April-May, which brings up cooler waters rich in nutrients, helping keep an average superficial seawater temperature around $22^{\circ} \mathrm{C}$ (Alfaro et al. 2012; Jiménez, 2001).

Sampling: The sampling focused mainly on solitary organisms since previous studies in this area have focused on colonial species. Samplings were carried out at depths between 1 and $13 \mathrm{~m}$ on rocky bottoms by roving with SCUBA gear, a metal spatula and/or a knife were used to carefully remove the specimens. Sampling in Bahía Tomas was carried out on an artificial substrate (fish breeding cages) at 1 $\mathrm{m}$ depth. A chisel and mallet were used to break up the substrate for specimens embedded in the rock to avoid sample damage.

Sample processing: The collected specimens were kept and transported in seawater, then anaesthetized by adding a mixture of 70 $\%$ alcohol and dissolved menthol crystals. This process can take several hours depending on the different morphological structures that characterize each one of the three ascidian 


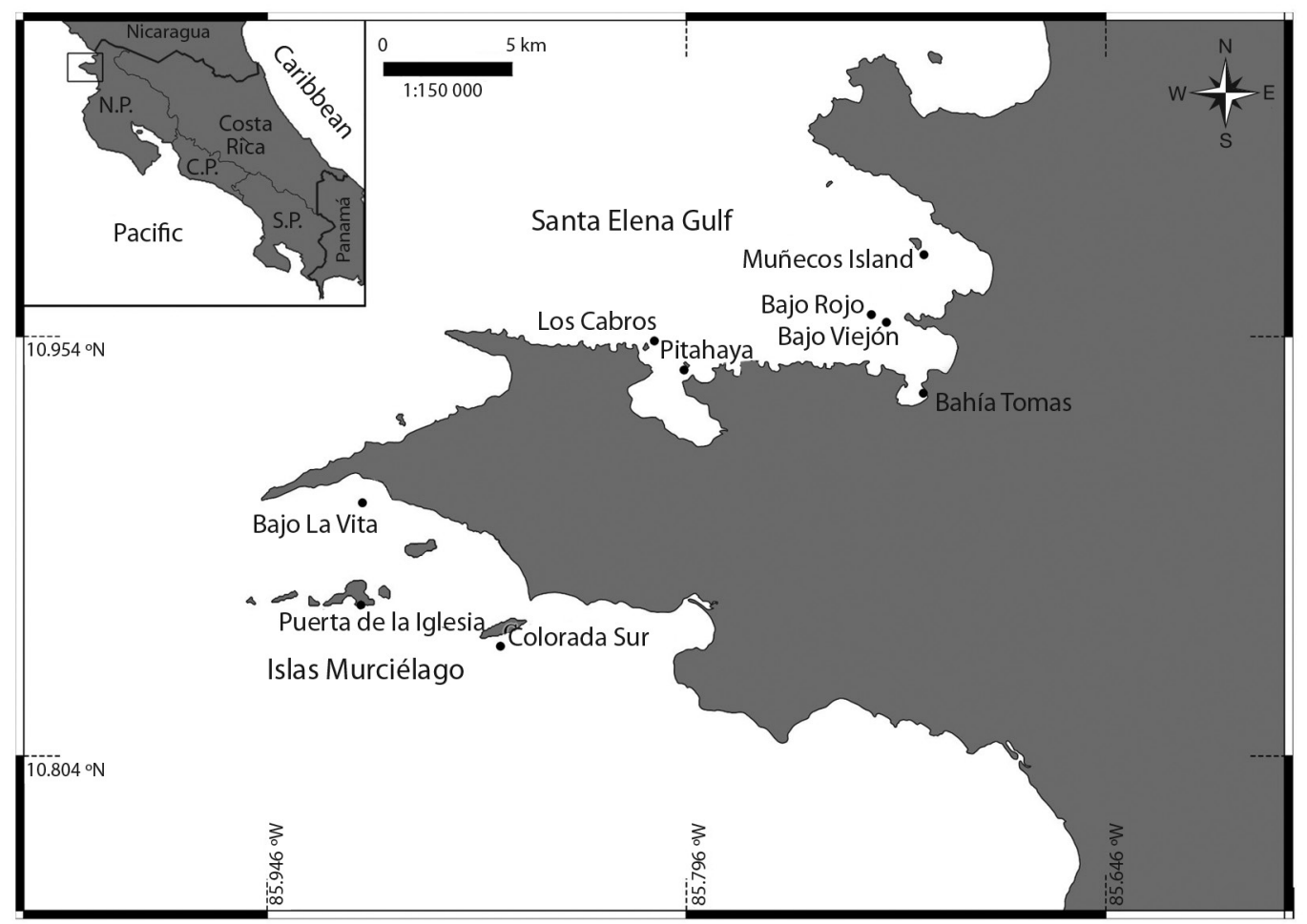

Fig. 1. Collecting sites in the Área de Conservación Guanacaste, North Pacific of Costa Rica. N.P.: North Pacific, C.P.: Central Pacific and, S.P.: South Pacific.

orders; being Stolidobranchia the one that takes more time due to the strong musculature, according to our observations. During this period, small amounts of $70 \%$ alcohol were added every hour to start the preservation process, without morphological alterations caused by alcohol fixation.

For the taxonomic identification, it was necessary to carry out a process of external and internal dissection of the organisms. This process began by opening the tunic with a cut from the atrial siphon to the oral one using dissection scissors, cutting carefully to avoid deep cuts that might cause internal structure damage. This was followed by a cut of the body wall in the same direction as in the previous cut. To visualize the internal structures, Harris's hematoxylin or Bengal Rose were used as a stain. To finish, the pharynx was removed, allowing the structures found inside to be observed. Monniot, Monniot and Laboute (1991) and
Rocha, Zanata and Moreno (2012) keys were used for taxonomic identifications, as well as the original descriptions of the species and taxonomic reviews of each species. Specimens were deposited at the Museum of Zoology of the University of Costa Rica.

Taxonomic list: Research on literature and collections databases of the National Museum of Natural History (NMNH), Smithsonian Institution (https://collections. nmnh.si.edu) were performed. Based on this information, and the new material collected for the present study in the North Pacific, an updated list of both solitary and colonial ascidians species present in Costa Rica was developed.

\section{RESULTS}

A total of eight species (70 specimens) were obtained from the sampling, corresponding to 
TABLE 1

Ascidian species (Subphylum Tunicata, Class Ascidiacea) found in different locations of Área de Conservación Guanacaste, North Pacific Costa Rica.

\begin{tabular}{|c|c|c|c|c|c|c|c|c|c|}
\hline \multirow{2}{*}{ Species } & \multicolumn{3}{|c|}{ Murciélago Islands } & \multicolumn{6}{|c|}{ Santa Elena Gulf } \\
\hline & PI & CS & BLV & BR & $\mathrm{BV}$ & MÑ & PT & TB & $\mathrm{LC}$ \\
\hline Ascidia sideralis & $\mathrm{X}$ & $\mathrm{X}$ & & $\mathrm{X}$ & & & $\mathrm{X}$ & & $\mathrm{X}$ \\
\hline Ascidia sidneyensis & & & & & & & $\mathrm{X}$ & $\mathrm{X}$ & \\
\hline Pyura lygnosa & & $\mathrm{X}$ & & & & $\mathrm{X}$ & $\mathrm{X}$ & & $\mathrm{X}$ \\
\hline Pyura carmanae & $\mathrm{X}$ & $\mathrm{X}$ & $\mathrm{X}$ & & & & $\mathrm{X}$ & & $\mathrm{X}$ \\
\hline Pyura bradleyi & & & & & & & $\mathrm{X}$ & $\mathrm{X}$ & \\
\hline Microsmus cf. exasperatus & & & & & & & $\mathrm{X}$ & $\mathrm{X}$ & \\
\hline Poliandrocarpa anguinea & & & & & & & $\mathrm{X}$ & & \\
\hline Rhopalaea birkelandi & & $\mathrm{X}$ & & $\mathrm{X}$ & $\mathrm{X}$ & $\mathrm{X}$ & $\mathrm{X}$ & & $\mathrm{X}$ \\
\hline
\end{tabular}

five genera, four families and three orders within the class Ascidiacea. The species richness was higher in Santa Elena Gulf (8 species) and lower in the Murcielago Islands (4 species). The most frequent species in both areas was Rhopalaea birkelandi Tokioka, 1971 (Table 1).

In our sampling, we found three of the 17 species previously reported, plus five new reports for the North Pacific area, totalling 22 species in Costa Rica (Table 2). From ascidians previously reported, 16 belong to the North Pacific and one to Puntarenas (Central Pacific).

\section{SYSTEMATICS}

In this section, we made a brief description of the eight species collected through our sampling in Área de Conservación Guanacaste. We only considered the most particular characteristics of the species or characteristics that have slight variations, mainly structure counts. These variations do not produce any changes in the taxonomic identity of the species and these are mentioned in order to broaden the known range in terms of the number of structures. The characteristics not mentioned in the description match with the original description of each species.
Subphylum Tunicata Lamarck, 1816

Class Ascidiacea Blainville, 1824

Order Phlebobranchia Lahille, 1886

Family Ascidiidae Herdman, 1882

Genus Ascidia Linnaeus, 1767

Ascidia sideralis Bonnet \& Rocha, 2013

Material Examined: 14 specimens (MZUCR-ASC-0066, MZUCR-ASC-0071, MZUCR-ASC-0079, MZUCR-ASC-0081, MZUCR-ASC-0089, MZUCR-ASC-0093).

Description: The specimens present a greyish tunic, whose coloration can vary to reddish and blue tones; characterized by the presence of white dots that become more abundant near the siphons and conspicuous musculature on the right side of the body. The individuals examined match with the original description by Bonnet, Rocha and Carman (2013); however, they present two remarkable differences. Individuals (two) with only four oral siphon lobes were found, thus expanding the range reported in the original description (from seven to eight lobes). The same situation occurs for the oral tentacles. Ranges from 76 to 92 tentacles were reported in the literature, but we found individuals with numbers ranging 
from 35 to 72 . Individuals belonging to this species are quite abundant in the North Pacific area (Fig. 2A).

Substrate: Rocky bottom.

Distribution: Panama (Bonnet et al., 2013) and Costa Rica (this study, North Pacific).

\section{Ascidia sydneiensis Stimpson, 1855}

Material Examined: six specimens (MZUCR-ASC-0072, MZUCR-ASC-0076).

Description: Individuals with pale greyish tunic and characterized for having a distinctive musculature, on the margin of the right side of the body, muscle fibers project from the margin to the interior without reaching the center. The characteristics of the examined specimens are consistent with the original description (Stimpson, 1855) and reports from Panama (Bonnet \& Rocha, 2011; Bonnet et al., 2013) (Fig. 2B).

Substrate: Artificial substrate.

Distribution: Australia (Stimpson, 1855), Brazil (Granthom-Costa et al., 2016), Cuba and Puerto Rico (Van Name, 1921), Guadeloupe and Martinique (Monniot, 1985), Costa Rica (this study, North Pacific), Panama (Carman et al., 2011), Colombia (Sluiter, 1898), Mozambique (Monniot \& Monniot, 1976), Zanzibar (Traustedt \& Weltner, 1891), South Africa (Millar, 1962), India (Swami \& Chapgar, 2002; Ali et al., 2009), Guam (Lambert, 2002), Virgin Islands, Belize, Mexico, French Polynesia, Hawaii, Japan, Phillipines and Papua New Guinea (https://collections.nmnh. si.edu/search/iz/).

Order Stolidobranchia Lahille, 1886

Family Pyuridae Hartmeyer, 1908

Genus Pyura Molina, 1782

\section{Pyura lignosa Michaelsen, 1908}

Material Examined: five specimens (MZUCR-ASC-0070, MZUCR-ASC-0074, MZUCR-ASC-0084).

Observations: A thick and robust tunic characterizes the collected specimens. The siphons are both in the apical position and have a globose shape with a greenish tonality, unlike their body, which is orange. In these individuals, the longitudinal vessels extend at the end of the folds near the esophagus. The observed characteristics of the specimens match the description provided by Michaelsen (1908) and the review by Monniot (1994) (Fig. 2C).

Substrate: Rocky bottom.

Distribution: Costa Rica (this study, North Pacific), Central Pacific (Michaelsen, 1908), Panama-Pacific (Carman et al., 2011), Mexico (Gulf of California) (Van Name, 1931), Majuro, Japan, Philippines (Nishikawa, 1984).

Pyura carmanae Rocha, 2019

Material Examined: 17 specimens (MZUCR-ASC-0083, MZUCR-ASC-0085, MZUCR-ASC-0090, MZUCR-ASC-0091, MZUCR-ASC-0094).

Observations: The characteristics of these individuals match with those given in the original description of the species (Rocha \& Counts, 2019). Three specimens differ in the position of the siphons, since they are widely separated one from each other: the oral in apical position and the exhalant in a lateral position. One of these three specimens has gonads only on the left side of the body wall, larger than in other specimens, and completely covering the first intestinal loop. These three individuals could be a different species, but related to $P$. carmanae. However, two of these specimens did not present gonads, so we could not make a satisfactory comparison between the internal structures of these three with the rest of the examined specimens. We consider the use of genetic tools to test this hypothesis. (Fig. 2D, Fig. 2E).

Although it has already been pointed out by Rocha and Counts (2019), it is important to mention that Tokioka (1972) described organisms belonging to the species $P$. carmanae as Pyura vittata. In this updated list we discard the presence of $P$. vittata as part of the Costa Rican marine fauna studied so far.

Substrate: Rocky bottom. 
Distribution: Panama (Rocha \& Counts, 2019), Costa Rica (this study, North Pacific).

\section{Pyura bradleyi Van Name, 1931}

Material Examined: three specimens (MZUCR-ASC-0075, MZUCR-ASC-0078, MZUCR-ASC-0092).

Observations: The individuals examined had an opaque tunic covered by sand, which matches with the reported by Van Name (1931) in the original species description. Furthermore, when observing the internal structures, a strong red coloration can be seen on the siphons and the whole mantle has a reddish color. Under its branched tentacles, red dots can be observed, which are also present under the branchial sac. Similar to that observed by Van Name (1931), its dorsal lamina is divided into barbs and there are six folds on each side of the body. Regarding the original description, these specimens showed a remarkable difference in terms of the number of gonadal sacs. The original description indicates that there are about 50 elongateoval sacs per gonad; our specimens showed up to 106 on the left side and 99 on the right side, increasing the range for this characteristic (Van Name, 1931). (Fig. 2F).

Substrate: Rocky bottom and artificial substrate.

Distribution: Peru (Van Name, 1931), Ecuador (Van Name, 1931) and Costa Rica (this study, North Pacific).

Genus Microcosmus Heller, 1877

Microcosmus cf. exasperatus Heller, 1878

Material examined: seven specimens (MZUCR-ASC-0077, MZUCR-ASC-0082).

Observations: Large individuals, up to $4.5 \mathrm{~cm}$ in length, with a dark reddish tunic, the mantle has a mixture of light orange and yellow. In general, the characteristics of the examined specimens match with the original description of the species (Van Name, 1945). Furthermore, they match with the diagnosis reported by Rocha, Bonnet, Baptista and Beltramin (2012). However, we have not been able to properly find the velum of these individuals in order to check the presence and shape of the spines, and therefore, to confirm the specimens identification (Fig. 2G). It is the first time that $M$. cf. exasperatus has been reported in Costa Rica.

Substrate: Rocky bottom and artificial substrate.

Distribution: Bermuda, U.S. (Florida), Cuba, Jamaica, Haiti, Puerto Rico, Saint Thomas, St. Lucia, Guadalupe, Martinica, Granada, Belize, Panama, Colombia, Aruba, Curaçao, Venezuela, Brazil (Ceará to Santa Catarina), Senegal, Sierra Leone, Liberia, Ghana, South Africa (Rocha, Zanata and Moreno, 2012), Israel, India (Ratnasingham \& Hebert, 2007), Mediterranean Sea, Atlantic Ocean, IndoPacific (Rocha, Bonnet, et al., 2012) and Costa Rica (North Pacific).

Family Styelidae Sluiter, 1895

Genus Polyandrocarpa Michaelsen, 1904

Polyandrocarpa anguinea Sluiter, 1898

Material examined: one specimen (MZUCR-ASC-0086).

Observations: Grayish and translucent colonies with a cartilaginous tunic; zooids more than $1 \mathrm{~cm}$ long. The zooids had approximately 25 smooth tentacles of two interspersed sizes and four folds on both sides of the branchial sac, which coincides with that described by Rodríguez (1977) and Rocha and Faria (2005) (Fig. 2H).

Substrate: Rocky bottom.

Distribution: South Africa, Brazil, Mozambique in the Eastern Atlantic, Mauritius in the Indian Ocean, and in the Tropical Pacific Ocean (Monniot, 1987), Martinica (Monniot, 2018), Panama (Carman et al., 2011), United States (Florida) (Ratnasingham \& Hebert, 2007) and Costa Rica (this study, North Pacific).

Order Aplousobranchia Lahille, 1886

Family Diazonidae Seeliger, 1906

Genus Rhopalaea Philippi, 1843 
Rhopalaea birkelandi Tokioka, 1971

Material examined: 17 specimens (MZUCR-ASC-0067, MZUCR-ASC-0068, MZUCR-ASC-0069, MZUCR-ASC-0073, MZUCR-ASC-0080, MZUCR-ASC-0087, MZUCR-ASC-0088).

Observations: In the examined specimens we noticed two different colors for the tunic: pink and blue. Tokioka (1971) describes this specie as solitary, however, we observed that the blue individuals were linked under the substrate. As for the pink individuals, we observed that they are much more abundant. All the specimens were found mainly on porous rocks, where their tunic extends through the crevices, up to about $10 \mathrm{~cm}$.
Rhopalaea birkelandi has two body parts separated by a thin and fragile peduncle. This, added to the insertion of the tunic in the rock, can lead to the separation of both sections during the extraction and dissection process. Comparing the original description of the species with our specimens, we noted that the peduncle is not mentioned. On the other hand, the original illustrations coincide with the morphology that we found in the specimens whose peduncle was damaged and consequently, the abdomen and thorax separated. Because of this, we believe that Tokioka may not have had access to specimens of $R$. birkelandi in good condition and thus, the description may be incomplete. (Fig. 2I, Fig. 2J, Fig. 2K).

Substrate: Rocky bottom.

TABLE 2

Complete list of ascidian species reported for Costa Rica.

\begin{tabular}{|c|c|c|}
\hline Order/Family & Species & Reported by \\
\hline \multicolumn{3}{|l|}{ Aplousobranchia } \\
\hline \multirow[t]{2}{*}{ Diazonidae } & Rhopalaea birkelandi (Tokioka, 1971) & $\begin{array}{c}\text { Tokioka, 1971, 1972; Nova et al,. 2010; } \\
\text { NMNH; this study }\end{array}$ \\
\hline & Rhopalaea abdominalis (Sluiter, 1898) & NMNH \\
\hline \multirow[t]{6}{*}{ Didemnidae } & Didemnum cf. perlucidum (Monniot, 1983) & Roth et al., 2017 \\
\hline & Didemnum moseleyi (Herdman, 1886) & Tokioka, 1972; Nova et al., 2010 \\
\hline & Didemnun candidum (Savigny, 1816) & Tokioka, 1972 \\
\hline & Lissoclinum caulleryi (Ritter \& Forsyth, 1917) & Tokioka, 1972; Nova et al., 2010 \\
\hline & Lissoclinum fragile (Van Name, 1902) & Tokioka, 1972 \\
\hline & Diplosoma listerianum (Milne- Edwards, 1841) & NMNH \\
\hline Polycitoridae & Cystodytes dellechiajei (Della Valle, 1877) & $\mathrm{NMNH}$ \\
\hline \multirow[t]{2}{*}{ Polyclinidae } & Aplidium constellatum $*$ (Van Name, 1902) & Tokioka, 1972 \\
\hline & Polyclinum laxum (Van Name, 1945) & Tokioka, 1972 \\
\hline \multicolumn{3}{|l|}{ Phlebobranchia } \\
\hline \multirow[t]{3}{*}{ Ascidiidae } & Ascidia ceratodes (Huntsman, 1912) & Tokioka, 1972; Nova et al., 2010 \\
\hline & Ascidia sydneiensis (Stimpson, 1855) & This study \\
\hline & Ascidia sideralis (Rocha, 2011) & This study \\
\hline \multicolumn{3}{|l|}{ Stolidobranchia } \\
\hline \multirow[t]{4}{*}{ Pyuridae } & Microcosmus cf. exasperatus (Heller, 1878) & This study \\
\hline & Pyura bradleyi (Van Name, 1931) & This study \\
\hline & Pyura carmanae (Rocha, 2019) & This study \\
\hline & Pyura lignosa (Michaelsen, 1908) & Tokioka, 1972; this study \\
\hline \multirow[t]{4}{*}{ Styelidae } & Botryllocarpa viridis* (Pizon, 1908) & Tokioka, 1972 \\
\hline & Eusynstyela tincta* (Van Name, 1902) & Tokioka, 1972; Nova et al., 2010; NMNH \\
\hline & Polyandrocarpa anguinea (Sluiter, 1898) & This study \\
\hline & Styela canopus* (Stimpson, 1852) & Tokioka, 1972 \\
\hline
\end{tabular}

*Species name has been modified according to WoRMS database. 

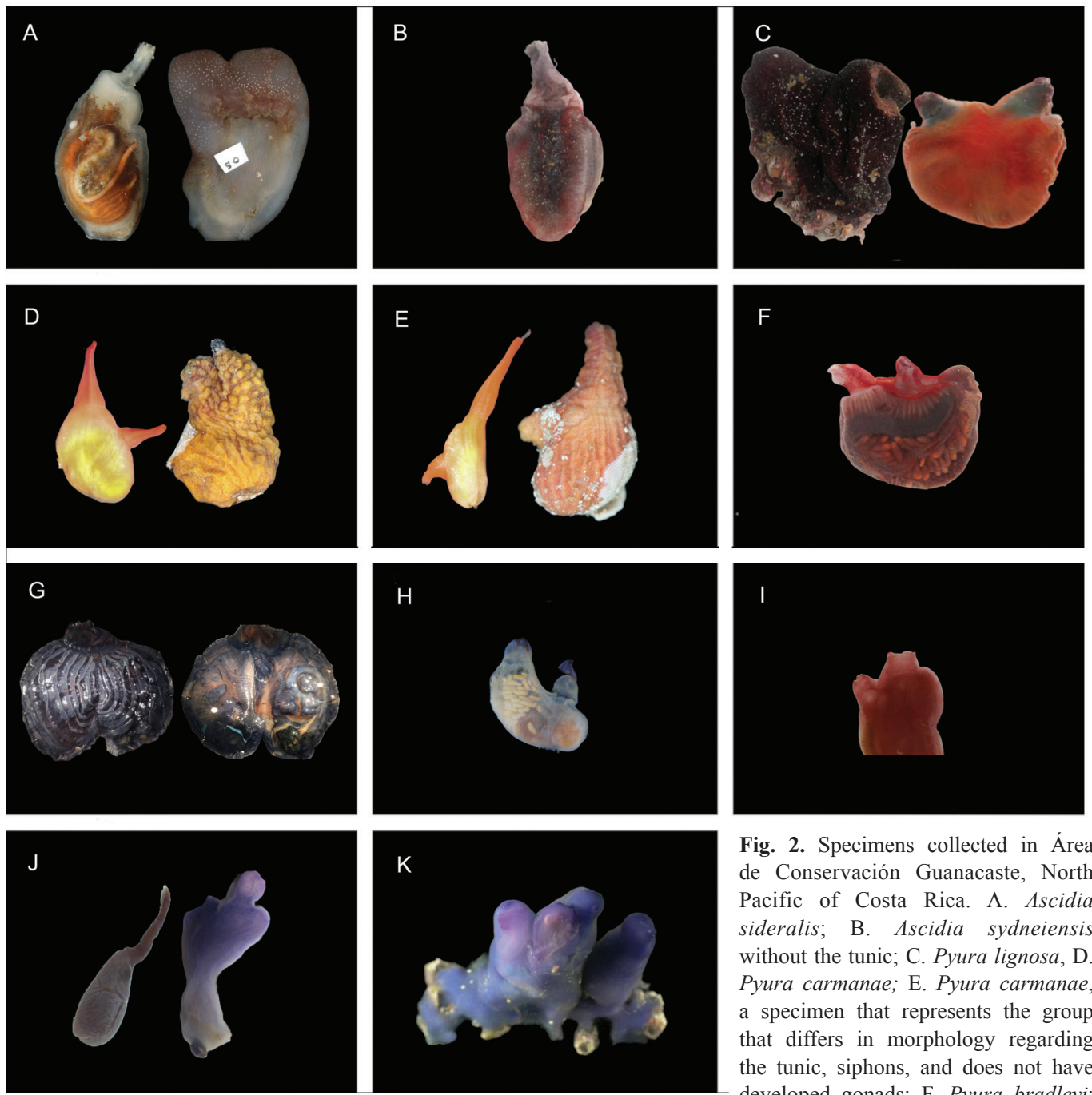

Fig. 2. Specimens collected in Área de Conservación Guanacaste, North Pacific of Costa Rica. A. Ascidia sideralis; B. Ascidia sydneiensis without the tunic; C. Pyura lignosa, D. Pyura carmanae; E. Pyura carmanae, a specimen that represents the group that differs in morphology regarding the tunic, siphons, and does not have developed gonads; F. Pyura bradleyi;

G. Microcosmus cf. exasperatus; H. Polyandrocarpa anguinea zooid; I. Rhopalaea birkelandi, pink specimen without tunic; J. Rhopalaea birkelandi blue zooid, on the left side the abdomen, on the right side the thorax; K. Colony of $R$. birkelandi with four blue zooids. Scale $=1 \mathrm{~cm}$.

Distribution: Costa Rica (North Pacific) (Tokioka, 1971; Tokioka, 1972; Nova et al., 2010; this study), Panama (Carman et al., 2011) and Mexico (Baja California Sur) (Ratnasingham \& Hebert, 2007).

\section{DISCUSSION}

Considering that ascidians have been barely studied in Costa Rica, this research shows the necessity of new sampling efforts to increase the known diversity. The present study reports for the first time the presence of five species in the Costa Rican Pacific and delivers an updated list of the 22 species of ascidians reported for Costa Rica.

The species richness and abundance in Santa Elena Gulf was higher than in Murcielago Islands. Both regions are under the effects of the seasonal upwelling phenomenon, 
which affects the entire North Pacific region (Alfaro et al., 2012; Rodríguez, \& Morales, 2012). On the other hand, Santa Elena Gulf is an important artisanal fishing point, in contrast to the Murcielago Islands, which are within the protected Marine Sector of the Área de Conservación Guanacaste. Other studies have reported a greater abundance of ascidians in areas around human activity, which generates movement of organic particles that constitute food for ascidians and facilitate their growth (Naranjo, Carballo, \& García-Gómez, 1996). The anthropic influence in Santa Elena Gulf could explain a higher ascidian diversity.

Rhopalaeae birkelandi is the most common and abundant species in our study, similarly, it has been reported as abundant and conspicuous in the rocky reefs of the Pacific of Central America (Tokioka, 1972). Nova and colleagues (2010) also found this species as the most abundant, reporting densities of up to 32 individuals per $\mathrm{m}^{2}$ in Cuajiniquil Bay. The presence of vanadocytes and the high acidity $(\mathrm{pH}<2)$ of their tunic, mainly near the siphons, can reduce epibionts and predation, being abundant in sites with a high predation rate (Stoecker, 1980).

Before this study, there were 17 ascidian species reported for Costa Rica; from these, 13 are colonial. We found only three of the previous ascidians reported ( $R$. birkelandi, Pyura lignosa and Poliandrocarpa anguinea) but our study was focused on the diversity of solitary ones. This approach allowed us to report five species of solitary ascidians for the first time. It is noteworthy that we did not find Ascidia ceratodes, despite being solitary and having been reported as common in the area (Nova et al., 2010).

The marine regions of Costa Rica are considered rich in terms of species diversity (Wehrtmann, Cortés, \& Echeverría, 2009). In the case of ascidians, there are reports for only one region of the country, the North Pacific (Cortés, 2009). Most of the studies took place in that region of Costa Rica or referred to individuals collected in that area. Differences in sampling effort, and not a low ascidian diversity in other regions, can explain this lack of data. Costa Rica's ascidian species inventory is undoubtedly underestimated. In a close by area of the Caribbean, Northwestern Panama, Rocha and colleagues (2005) reported a total of 58 ascidian species, from which 14 were new to science. In fact, we have observed the presence of colonial ascidians in regions such as Cahuita and Punta Uva, on the South Caribbean of Costa Rica, without having the opportunity to study them until now.

Among the ascidians reported in Costa Rica, we find $P$. anguinea, a species that has been introduced to many countries around the world (Evans et al., 2017). This species, native of Mozambique (Sluiter, 1989), has been found in Brazil (Rodríguez, 1977), Panama (Carman et al., 2011), Mauritius (Monniot, 1987), Martinique (Monniot, 2018) and the Atlantic Ocean in the United States (Villalobos, Lambert, Shenkar, \& López-Legentil, 2017). Some introduced species could become invasive (Blackburn et al., 2011), changing the ecosystems by modifying ecological relations and even harming the survival of native species (Evans et al., 2017; Molnar, Gamboa, Revenga, \& Spalding, 2008). Taking into account the ability of $P$. anguinea to become invasive, we recommend monitoring the population of this species in the country.

In conclusion, new samplings in the North Pacific and the compilation of previous reports from the literature allowed us to extend the known diversity of ascidians in Costa Rica, updating the knowledge about this group. We report five species for the first time and provide a list that includes until now, 22 species in total, the majority found in the North Pacific region. Different sampling efforts, but not presumably low ascidian diversity in other regions, suggest the necessity of samplings along with other places in the Pacific and the Caribbean, which for the latter there are no reports. Future investigations should include colonial ascidians, the use of molecular tools, and ecological studies that can clarify the importance of ascidians, and also monitor the impact of exotic species in the area. 
Ethical statement: authors declare that they all agree with this publication and made significant contributions; that there is no conflict of interest of any kind; and that we followed all pertinent ethical and legal procedures and requirements. All financial sources are fully and clearly stated in the acknowledgements section. A signed document has been filed in the journal archives.

\section{ACKNOWLEDGMENTS}

This research was possible thanks to the BioMar-ACG project funded by the Guanacase Dry Forest Conservation Fund (GDFCF). Logistic support was provided by CIMAR, Universidad de Costa Rica (Project: Biodiversidad marina del Área de Conservación Guanacaste, Costa Rica: Proyecto BioMar-ACG: 808-B9-508). The authors would like to thank Yelba Vega, Gilbert Ampié and Fabio Quesada for the help provided during the collection and processing of samples. Special thanks to Rosana Rocha for all the support and advise throughout the process.

\section{RESUMEN}

\section{Diversidad de ascidias de Costa Rica, incluyendo nuevos reportes para el área del Pacífico Norte}

Introducción: La clase Ascidiacea tiene alrededor de 3000 especies, las cuales llevan a cabo varias funciones en el ecosistema, por ejemplo: filtrar altas cantidades de partículas y servir de refugio y alimento para otros animales. Asimismo, para el grupo se han reportado un gran número de especies invasoras. En Costa Rica las ascidias han sido poco estudiadas.

Objetivo: En el presente estudio buscamos describir la diversidad de ascidias en Costa Rica a partir de nuevos muestreos en el Área de Conservación Guanacaste, Pacífico Norte y mediante la recolección de reportes previos para el país para así aumentar el conocimiento del grupo. Métodos: Las muestras fueron colectadas en dos giras entre el 2018 y 2019, en seis sitios en el Golfo de Santa Elena y tres sitios cerca de las Islas Murciélago. Los especímenes fueron disectados y analizados en detalle para su identificación. Todas las identificaciones fueron comparadas con la información encontrada en la literatura y en colecciones de museos. Literatura, bases de datos de la colección del Museo Nacional de Historia Natural de la
Institución Smithsonian y el nuevo material colectado, fueron utilizados para crear un listado taxonómico actualizado. Resultados: Se obtuvo un total de ocho especies del muestreo. De estas, cinco son nuevos reportes, incrementando el total de especies reportadas en Costa Rica a 22. La especie más común fue Rhopalaea birkelandi, cuya presencia fue mayor en Bahía Santa Elena.

Conclusiones: Este estudio mejoró el conocimiento sobre la diversidad de ascidias en Costa Rica. Polyandrocarpa anguinea, reportada por primera vez, es considerada una especie invasora en otras áreas, lo que sugiere la necesidad de monitorear su población de forma continua. Es necesario incluir más áreas del país en futuros estudios puesto que casi todas las especies reportadas provienen del Pacífico Norte; la diversidad de otras partes del país, especialmente el Caribe permanece desconocida.

Palabras clave: Ascidiacea; distribución; sistemática; taxonomía; nuevos reportes.

\section{REFERENCES}

Abbott, D. P., Newberry, A. T., \& Morris, K. M. (1997). Reef and Shore Fauna of Hawaii. 6B: Ascidians (Urochordata). G. Lambert. Honolulu: Bishop Museum Press.

Alfaro, E. J., Cortés, J., Alvarado, J. J., Jiménez, C., León, A., Sánchez-Noguera, C., Nivia-Ruiz, J., \& Ruiz, E. (2012). Clima y temperatura sub-superficial del mar en Bahía Culebra, Golfo de Papagayo, Costa Rica. Revista de Biología Tropical, 60(Supplement 2), S159-S171.

Ali, H. A. J., Sivakumar, V., \& Tamilselvi, M. (2009). Distribution of alien and cryptogenic ascidians along the southern coasts of Indian peninsula. World Journal of Fish and Marine Sciences, 1, 305-312.

Blackburn, T. M., Pyšek, P., Bacher, S., Carlton, J. T., Duncan, R. P., Jarošík, V., Wilson, J. R. U., \& Richardson, D. M. (2011). A proposed unified framework for biological invasions. Trends in Ecology \& Evolution, 26(7), 333-339. https://doi.org/10.1016/j. tree.2011.03.023

Bonnet, N. Y. K., \& Rocha, R. M. (2011). The Ascidiidae (Ascidiacea: Tunicata) of Coastal Brazil.Zoological Studies, 50(6), 809-825.

Bonnet, N. Y. K., Rocha, R. M., \& Carman, M. R. (2013). Ascidiidae Herdman, 1882 (Tunicata: Ascidiacea) on the Pacific coast of Panama. Zootaxa, 3691(3), 351. https://doi.org/10.11646/zootaxa.3691.3.4

Carman, M. R., Bullard, S. G., Rocha, R. M., Lambert, G., Dijkstra, J. A., Roper, J. J., ... \& Vail, E. M. (2011). Ascidians at the Pacific and Atlantic entrances to the Panama Canal. Aquatic Invasions, 6(4), 371-380. 
Carrión-Cortez, J., Canales-Cerro, C., Arauz, R., \& Riosmena-Rodríguez, R. (2013). Habitat Use and Diet of Juvenile Eastern Pacific Hawksbill Turtles (Eretmochelys imbricata) in the North Pacific Coast of Costa Rica. Chelonian Conservation and Biology, 12(2), 235-245. https://doi.org/10.2744/CCB-1024.1

Cortés, J. (2009). Other taxonomic groups (Fungi, kinorhynchs, invertebrate chordates). In I. S. Wehrtmann, \& J. Cortés (Eds.), Marine Biodiversity of Costa Rica, Central America (pp. 497-500, Species list in CD pp. 491-492). Monographiae Biologicae 86. Dordrecht: Springer + Business Media B.V.

Darwin, J. H., \& Klebba K. (2007). New species and host associations of commensal leucothoid amphipods from coral reefs in Florida and Belize (Crustacea:Amphipoda). Zootaxa, 1494, 1-44

Evans, J. S., Erwin, P. M., Shenkar, N., \& López-Legentil, S. (2017). Introduced ascidians harbor highly diverse and host-specific symbiotic microbial assemblages. Scientific Reports, 7(1), 11033. https://doi. org/10.1038/s41598-017-11441-4

Fletcher, L., Forrest, B., \& Bell, J. (2013). Impacts of the invasive ascidian Didemnum vexillum on greenlipped mussel Perna canaliculus aquaculture in New Zealand. Aquaculture Environment Interactions, 4(1), 17-30. https://doi.org/10.3354/aei00069

Granthom-Costa, L., Ferreira, C., \& Dias, G. (2016). Biodiversity of ascidians in a heterogeneous bay from southeastern Brazil. Management of Biological Invasions, 7(1), 5-12. https://doi.org/10.3391/ mbi.2016.7.1.02

Jiménez, C. (2001). Seawater temperature measured at the surface and at two depths (7 and $12 \mathrm{~m})$ in one coral reef at Culebra Bay, Gulf of Papagayo, Costa Rica. Revista de Biología Tropical, 49, 153-161.

Lahille, F. (1886). Sur la classification des Tuniciers. Comptes rendus de l'Académie des sciences, 102, 446-448.

Lambert, G. (2002). Nonindigenous Ascidians in Tropical Waters. Pacific Science, 56(3), 291-298. https://doi. org/10.1353/psc.2002.0026

Lambert, G. (2007). Invasive sea squirts: A growing global problem. Journal of Experimental Marine Biology and Ecology, 342(1), 3-4. https://doi.org/10.1016/j. jembe.2006.10.009

Marin, I., \& Anker, A. (2008). A new species of Pontonia Latreille, 1829 (Crustacea, Decapoda, Palaemonidae) associated with sea squirts (Tunicata, Ascidiacea) from the Pacific coast of Panama. Zoosystema, 30(2), $501-515$

Michaelsen. W. (1908). Die Pyuriden (Halocynthiiden) des Naturhistorischen Museums zu Hamburg.
Mitteilungen aus dem Naturhistorischen Museum. 25(2), 227-287.

Millar, R. H. (1962). Further descriptions of South African ascidians. Annals of the South African Museum, 46(7), 113-221.

Molnar, J. L., Gamboa, R. L., Revenga, C., \& Spalding, M. D. (2008). Assessing the global threat of invasive species to marine biodiversity. Frontiers in Ecology and the Environment, 6(9), 485-492. https://doi. org $/ 10.1890 / 070064$

Monniot, C. (1985). Ascidies littorales de Guadeloupe. IX: Caractéristiques des populations, écologie, rapports avec la faune mondiale. Tethys, 11, 203-213

Monniot, C. (1987). Ascidies de Nouvelle-Calédonie. II: Les genres Polycarpa et Polyandrocarpa. Bulletin du Muséum national d'histoire naturelle. Section A, Zoologie, biologie et écologie animales, 9(2), 275-310.

Monniot, C. (1994) Pyura lignosa (s. s.), a Pacific ascidian from Central America, with descriptions of species confused under this name. Zoological Journal of the Linnaean Society, 110, 41-51.

Monniot, C., \& Monniot, F. (1976). Ascidies de la Côte du Mozambique. Revue de Zoologie Africaine. 90(2): 357-392.

Monniot C., Monniot F., \& Laboute P. (1991). Coral reef ascidians of New Caledonia. (30 ed.). Paris, Francia: Editions de l'ORSTOM

Monniot, F. (2018). Ascidians collected during the Madibenthos expedition in Martinique: 2 . Stolidobranchia, Styelidae. Zootaxa, 4410(2), 291-318.

Moreno-Dávila, B. (2013). Ascidians Biodiversity of Tropical Eastern Pacific. In R. Riosmena-Rodriguez (Ed.), Invertebrates: Classification, Evolution and Biodiversity (p. 181). New York: Nova Science Publishers, Inc.

Naranjo, S. A., Carballo, J. L., \& Garcia-Gomez, J. C. (1996). Effects of environmental stress on ascidian populations in Algeciras Bay (southern Spain). Possible marine bioindicators?. Marine Ecology Progress Series, 144, 119-131.

Nishikawa, T (1984) Ascidians from the Truk Islands, Ponape Island and Majuro Atoll (Tunicata, Ascidiacea). Proceedings of the Japanese Society of Systematic Zoology, 27, 107-140

Nova-Bustos, N., Hernández-Zanuy, A. C., \& ViquezPortuguez, R. (2010). Distribución y abundancia de las ascidias de los fondos rocosos de la Bahía de Cuajiniquil, Costa Rica. Boletín de Investigaciones Marinas y Costeras, 39(1), 57-66. 
Petersen, J. K. (2007). Ascidian suspension feeding. Journal of Experimental Marine Biology and Ecology, 342(1), 127-137.

Ratnasingham, S., \& Hebert, P. D. (2007). BOLD: The Barcode of Life Data System (http://www. barcodinglife. org). Molecular ecology notes, 7(3), 355-364.

Rocha, R. M., Bonnet, N. Y. K, Baptista, M. S., \& Beltramin, F. S. (2012). Introduced and native Phlebobranch and Stolidobranch solitary ascidians (Tunicata: Ascidiacea) around Salvador, Bahia, Brazil. Zoologia, 29(1), 39-53.

Rocha, R. M., \& Counts, B. K. (2019). Pyura (Tunicata: Ascidiacea: Pyuridae) on the coasts of Panama. Zootaxa, 4564(2), 491-513.

Rocha, R. M. D., \& Faria, S. B. D. (2005). Ascidians at Currais islands, Paraná, Brazil: taxonomy and distribution. Biota Neotropica, 5(2), 167-186.

Rocha, R. M., Zanata, T. B., \& Moreno T. R. (2012) Keys for identification of families and genera of Atlantic shallow water ascidians. Biota Neotropica, 12(1), 1-35. https://doi.org/10.1590/ S1676-06032012000100022

Rodríguez, K. S., \& Morales, A. R. (2012). Composición y distribución del mesozooplancton en una zona de afloramiento costero (Bahía Culebra, Costa Rica) durante La Niña 1999 y el 2000. Revista Biología Tropical, 60(Supplement 2), 143-157.

Rodríguez, S. A. (1977). Notes on Brazilian ascidians. II. On the records of Polyandrocarpa anguinea (Sluiter) e Polyandrocarpa maxima (Sluiter). Revista Brasileira de Biologia, 37(4), 721-726.

Shenkar, N., \& Swalla, B. J. (2011). Global Diversity of Ascidiacea. PLoS ONE, 6(6), e20657. https://doi. org/10.1371/journal.pone.0020657

Sluiter, C. (1898). Beitrage zur Kenntnis der Fauna von Sudafrica II. Tunicaten. Zoologischen Jahrbücher Systematik, 11, 1-64.

Stefaniak, L. (2009). Genetic conspecificity of the worldwide populations of Didemnum vexillum Kott, 2002. Aquatic Invasions, 4(1), 29-44. https://doi. org/10.3391/ai.2009.4.1.3

Stimpson, W. (1855). Descriptions of some of the new Marine Invertebrata from the Chinese and Japanese Seas. Proceedings of the Academy of Natural Sciences, Philadelphia, 7(10), 375-384.
Stoecker, D. (1980). Chemical Defenses of Ascidians Against Predators. Ecology, 61(6), 1327-1334. https:// doi.org/10.2307/1939041

Swami, B. S., \& Chapgar, B. F. (2002). Settlement pattern of ascidians in harbor waters of Mumbai, West Coast of India. Indian Journal of Marine Science, 31, 207-212.

Tokioka, T. A. (1971). A New Species of Rhopalaea from the Pacific coast of Costa Rica (Tunicata, Ascidiacea). Publications of the Seto Marine Biological Laboratory, 19(2), 119-122.

Tokioka, T. (1972). On a Small Collection of Ascidians from the Pacific Coast of Costa Rica. Publications of the Seto Marine Biological Laboratory, 19(6), 383-408. https://doi.org/10.5134/175738

Traustedt, M., \& Weltner, W. (1891). Bericht über die von Herrn Dr. Sander gesammelten Tunicaten. Archiv für Naturgeschichte, 60, 10-14.

Turon, X., Casso, M., Pascual, M., \& Viard, F. (2020). Looks can be deceiving: Didemnum pseudovexillum sp. nov. (Ascidiacea) in European harbours. Marine Biodiversity, 50(4), 48. https://doi.org/10.1007/ s12526-020-01083-7

Van Name, W. G. (1921). Ascidians of the West Indian region and south eastern United States. Bulletin of the American Museum of Natural History, 44(16), 283-494.

Van Name, W. G. (1931). New North and South American Ascidians. Bulletin of the American Museum of Natural History, 59, 207-225.

Van Name, W. G. (1945). The North and South American ascidians. Bulletin of the American Museum of Natural History, 84, 1-476.

Villalobos, S., Lambert, G., Shenkar, N., \& López-Legentil, S. (2017). Distribution and population dynamics of key ascidians in North Carolina harbors and marinas. Aquatic Invasions, 12(4), 447-458. https://doi. org/10.3391/ai.2017.12.4.03

Wehrtmann, I. S., Cortés, J., \& Echeverría-Sáenz, S. (2009). Marine Biodiversity of Costa Rica: Perspectives and Conclusions. In I. S. Wehrtmann, \& J. Cortés (Eds.), Marine Biodiversity of Costa Rica, Central America (pp. 521-533). Netherlands: Springer. https://doi.org/10.1007/978-1-4020-8278-8 49 